\title{
Extraordinary numbers of giant squid, Architeuthis dux, encountered in Japanese coastal waters of the Sea of Japan from January 2014 to March 2015
}

\author{
Tsunemi Kubodera $^{1}$ (1) $\cdot$ Toshifumi Wada $^{2} \cdot$ Masahito Higuchi $^{3} \cdot$ Akiko Yatabe
}

Received: 21 July 2016/Revised: 22 October 2016 / Accepted: 29 November 2016 /Published online: 24 December 2016

(C) The Author(s) 2016. This article is published with open access at Springerlink.com

\begin{abstract}
In total, 57 giant squid, Architeuthis dux, were found between January 2014 and March 2015 in Japanese coastal waters in the Sea of Japan. Occurrences were especially high around Sado Island and in Toyama Bay. All of the squid occurred individually, and 28 were found alive. The occurrences were categorized into three groups based on distance from the shore and the depth at which they were found: (1) washed ashore on a beach or found floating at the surface close to a beach (19 individuals); (2) caught in a fixed net set in coastal waters between 50 and $150 \mathrm{~m}$ depths (28 individuals); and (3) caught by bottom trawl or bottom gillnet fisheries several kilometers offshore between 200 and $300 \mathrm{~m}$ depths (ten individuals). Two size groups were recognized, one ranging between 80 and $160 \mathrm{~cm}$ dorsal mantle length (DML) with a mode at $110 \mathrm{~cm}$ and another larger than $160 \mathrm{~cm}$ DML. The sex ratio in the smaller group was nearly equal and the larger group was comprised of all females. The Sea of Japan was considered to be a large natural trap for giant squid migrating through southwestern Tsushima Strait.
\end{abstract}

Communicated by M. Vecchione

Electronic supplementary material The online version of this article (doi:10.1007/s12526-016-0618-7) contains supplementary material, which is available to authorized users.

Tsunemi Kubodera

kubodera@kahaku.go.jp

1 National Museum of Nature and Science, Tsukuba Research Institute, 4-1-1 Amakubo, Tsukuba, Ibaraki 305-0005, Japan

2 Institute of Natural and Environmental Sciences, University of Hyogo, Yayoigaoka 6, Sanda, Hyogo 669-1546, Japan

3 Niigata Prefectural Fisheries and Marine Institute, 13098-8 Ikarashi Sanno-cho, Nishi Ward, Niigata 950-2171, Japan
Keywords Giant squid · Sea of Japan · Japanese coastal waters · Winter

\section{Introduction}

The giant squid is well known as one of the largest marine invertebrates. Not only marine biologists but also the general public have been fascinated by this elusive creature due to their depiction in popular sci-fi novels and movies (Ellis 1998). Since the first species of giant squid, Architeuthis $d u x$, was described by Steenstrup in 1857 , more than a dozen ill-described and poorly understood Architeuthis species have been reported from all over the world (Clarke 1966, 1980; Roper and Boss 1982). In Japanese waters, two nominal species, A. martensii (Hilgendorf, 1880) and A. japonica Pfeffer, 1912, the latter of which was named based on "Notes on a gigantic cephalopod" by Mitsukuri and Ikeda (1895), were initially described. However, systematic description of A. martensii was inadequate for a distinct species; thus, A. japonica had been applied to the giant squid in Japanese waters (Sasaki 1916, 1929; Taki 1965). In the early 1980s, Roper and Boss (1982) suggested that the 19 nominal species identified at that time actually comprised only three species, A. $d u x$ in the northern Atlantic, A. japonica in the northern Pacific, and A. sanctipauli in the Southern Hemisphere.

Roeleveld and Lipinski (1991) gave detailed descriptions of the external and internal morphology of the giant squid based on three specimens from southern African waters. They recognized that the three specimens were actually a single species but they hesitated to give it a species name. Förch (1998) examined 16 specimens of Architeuthis obtained from New Zealand waters and revealed that there was very high inter-individual variability in external and internal morphology. Förch (1998) recommended that the family 
Architeuthidae be reduced to a single genus and species, $A$. $d u x$, consistent with the earliest adequate systematic description. Recent genetic study on whole mitochondrial DNA of the giant squid (Winkelmann et al. 2013) demonstrated that there was no detectable phylogenetic structure at the mitochondrial level among 43 samples obtained from oceans all over the world, and the level of nucleotide diversity was exceptionally low. These results strongly support the hypothesis that only one global species, $A$. $d u x$, is valid.

Historically in Japan, giant squid have occasionally washed ashore or been seen floating at the surface of coastal waters of the Sea of Japan, and such sightings have become local news media stories (Nishimura 1968; Honma et al. 1983). Okiyama (1993) accumulated occurrence data between 1941 and 1971, creating a distribution map and monthly occurrences based on 20 records. Findings were scattered along the coasts of Shimane, Tottori, Hyogo, Kyoto, Ishikawa, Toyama, and Niigata Prefectures, as well as Sado Island. Seasonally, the giant squid has appeared in limited numbers in the winter from December to March and has been most abundant in February. Okiyama (1993) observed mass occurrences in the winters of 1974-75 (six records) and 1975-76 (seven records), and suggested that significant recruitment of giant squid occurred twice in these two successive years through the Tsushima Strait. Since 1998, the senior author of the current study has compiled giant squid occurrences in Japanese waters and recorded 19 sightings in the Sea of Japan as of March 2012. On average, one or two individuals appear every 2 years, but an exceptional six individuals were found in the winter of 2006-07 (Kubodera 2013).

During two winter seasons of 2014-2015, 57 individuals were found in Japanese coastal waters of the Sea of Japan. No such mass occurrence of giant squid has ever been reported from any corner of the world. Therefore, we present detailed information of each encounter and the known biological data for each individual. We discuss hypothetical scenarios to explain the mass findings of giant squid in 2014 and 2015 based on the oceanographic characteristics of the Sea of Japan and other factors.

\section{Materials and methods}

Whenever an extraordinarily large squid was discovered and brought to the attention of the prefectural fisheries research center, museum, or aquarium, staff were sent to identify and examine the specimen, including measurement and photographs, and to interview the public member(s) who found the squid. The news media was often present and reported the sightings in the local newspapers and on television.

From January 2014 to March 2015, 57 individuals of extralarge squid were discovered along the coastal area of the Sea of Japan, all of which were identified as $A$. dux based on photos and short notes sent by local experts and/or media reports. In addition to those communications, the second author actually visited most of the sites in the western part of the sighting area in 2014 to collect accurate data and specimens, and the third author similarly covered the sites in Niigata Prefecture and Sado Island.

To understand the oceanographic condition of the Sea of Japan, we referred to tri-monthly 10-day mean horizontal water temperature profiles and temperature anomalies at the surface and at depths of 50, 100, and $200 \mathrm{~m}$ from December 2013 to March 2015 obtained from the Japan Meteorological Agency (JMA) (http://www.data.jma.go. jp/gmd/kaiyou/data/db/kaikyo/jun/t100_NK.html). In addition, vertical temperature profiles along the PM line (off Echizen Peninsula) and JAY line (from Nihonkai Basin to Yamato Basin) as observed by JMA research vessels in November 2013 were collected (http://www.data.jma.go. jp/gmd/kaiyou/db/vessel_obs/maizuru/index.php?id=2013 aut).

\section{Results}

The date and location of encounter, situation at finding, depth, type of person who found the squid, person confirming the sighting, and other remarks are summarized in Table 1. The geographic location of each find is plotted in Fig. 1. Biological data of each squid, such as dorsal mantle length (DML; measured dorsally from the tip of the fin to the anteriormost point of the mantle), body length (BL; from the tip of the fin to the longest arm tip), total length (TL; from the tip of the fin to the distal end of the stretched tentacle), body weight (BW), sex, and condition when found are summarized in Table 2. The Appendix presents cases where photos were available.

In total, 57 individuals (24 from January to May 2014 and 33 from September 2014 to March 2015) were found, all of which were confirmed to be giant squid.

\section{Records of findings}

Giant squid appeared broadly along the Japanese coast from Yamaguchi to Niigata, and high occurrences were seen around Sado Island in January-May 2014 and in Toyama Bay in September 2014-March 2015, with one exception of the northernmost record from Aomori Prefecture (Fig. 2). In total, 29 individuals out of 57 were actually found in Niigata and Toyama Prefectures.

Giant squid appeared in the winter months and disappeared during the summer months. High occurrences were seen in March-April 2014 and in January-February 2015 (Fig. 3). 


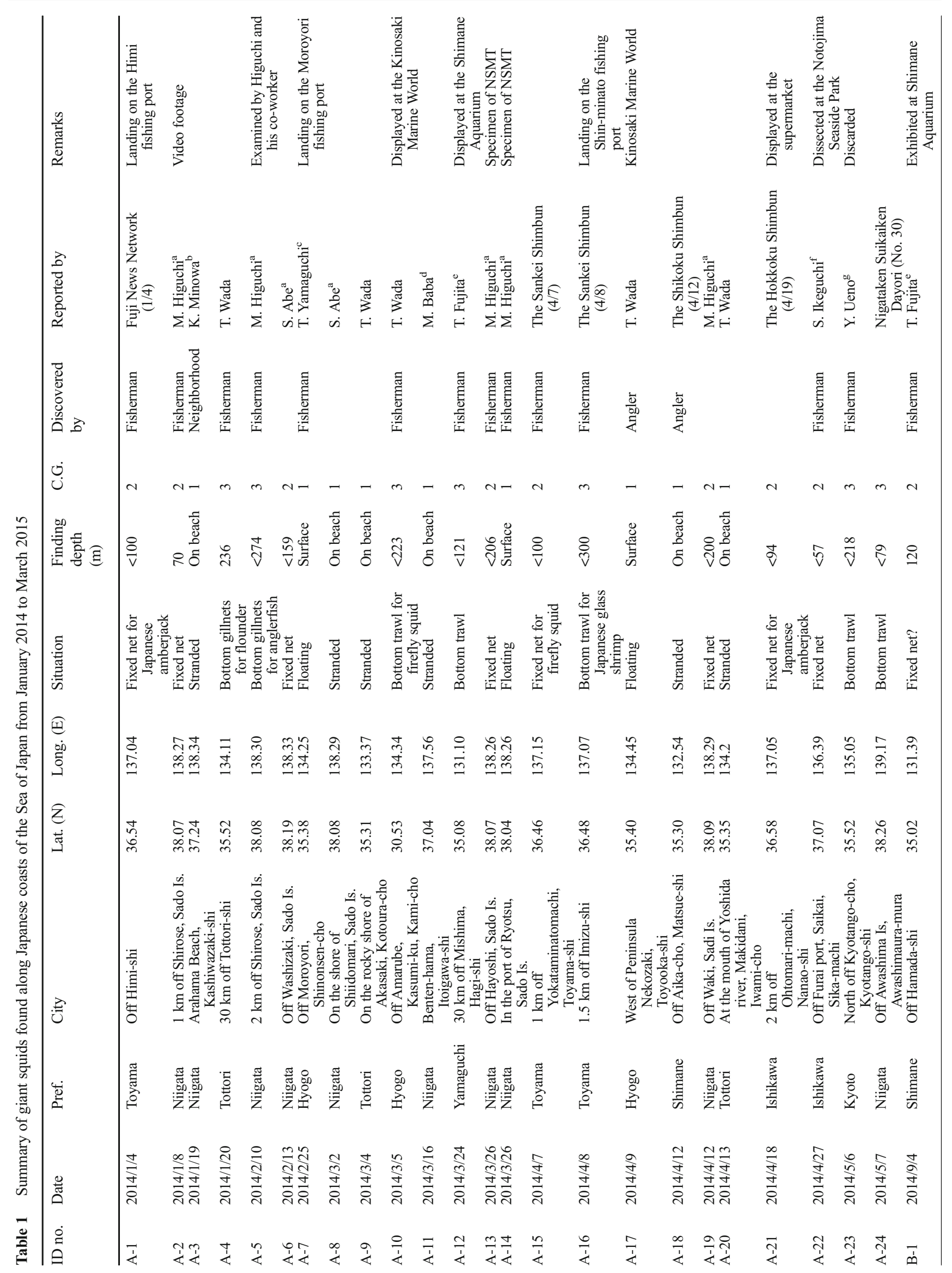




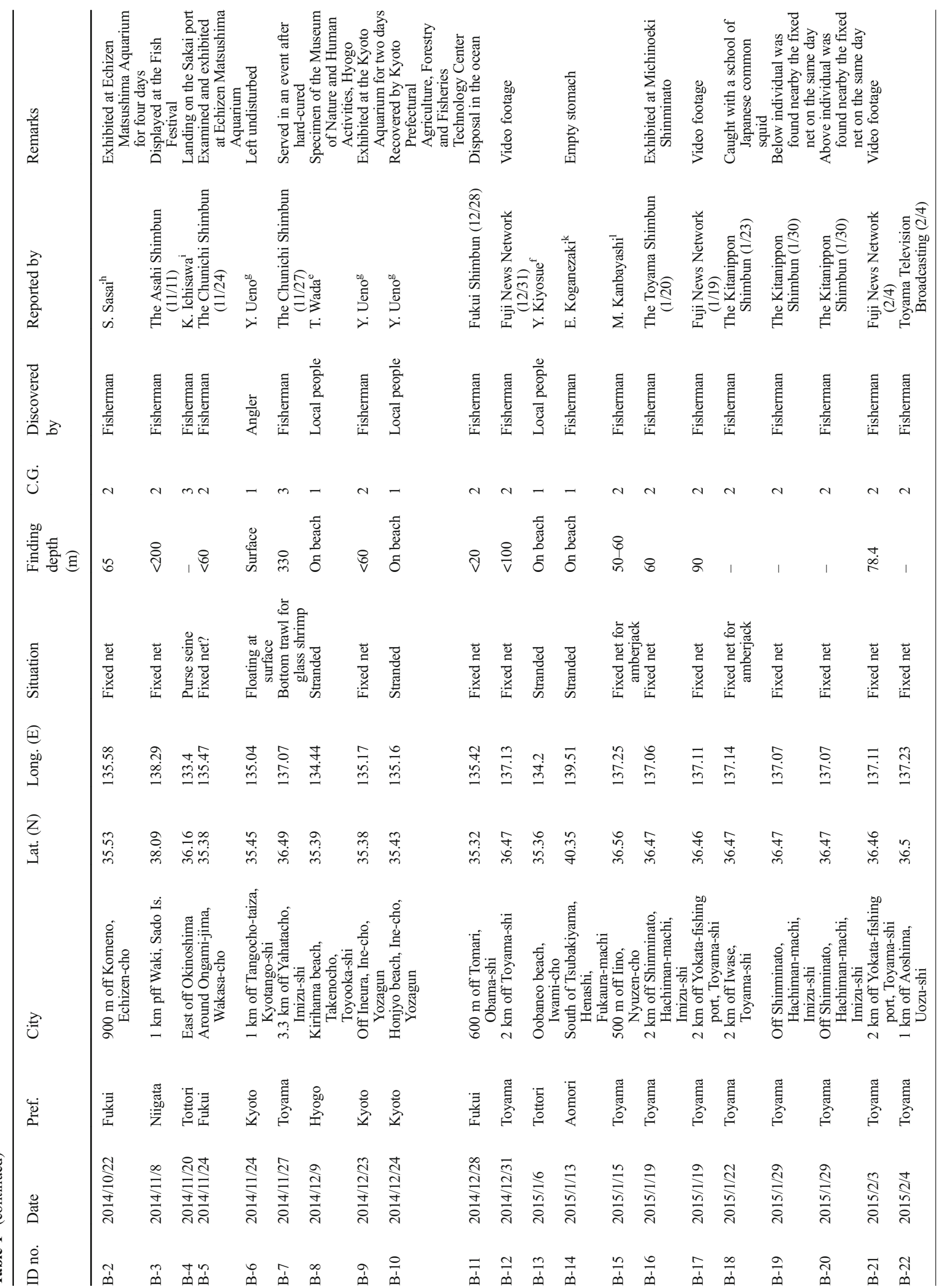




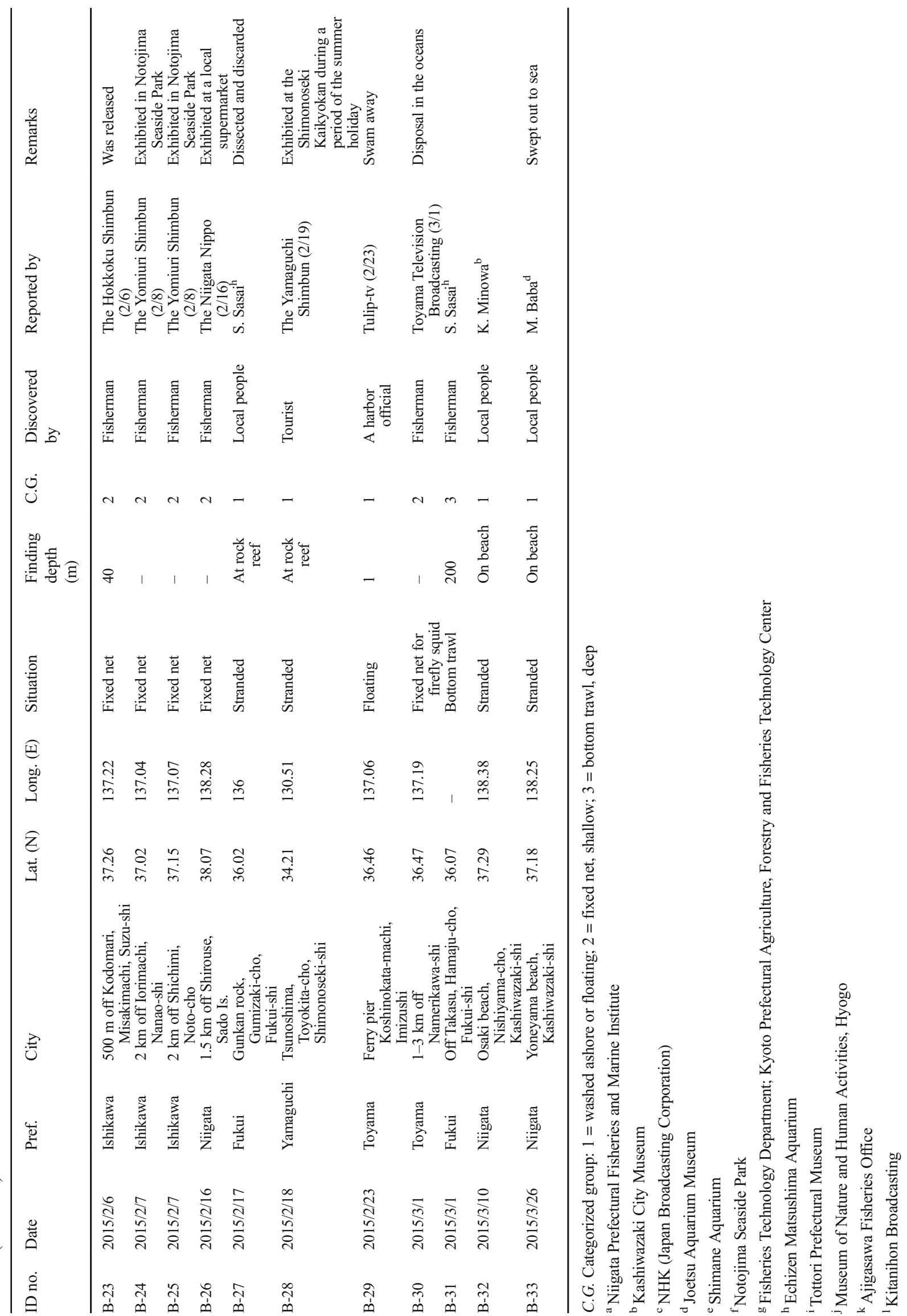




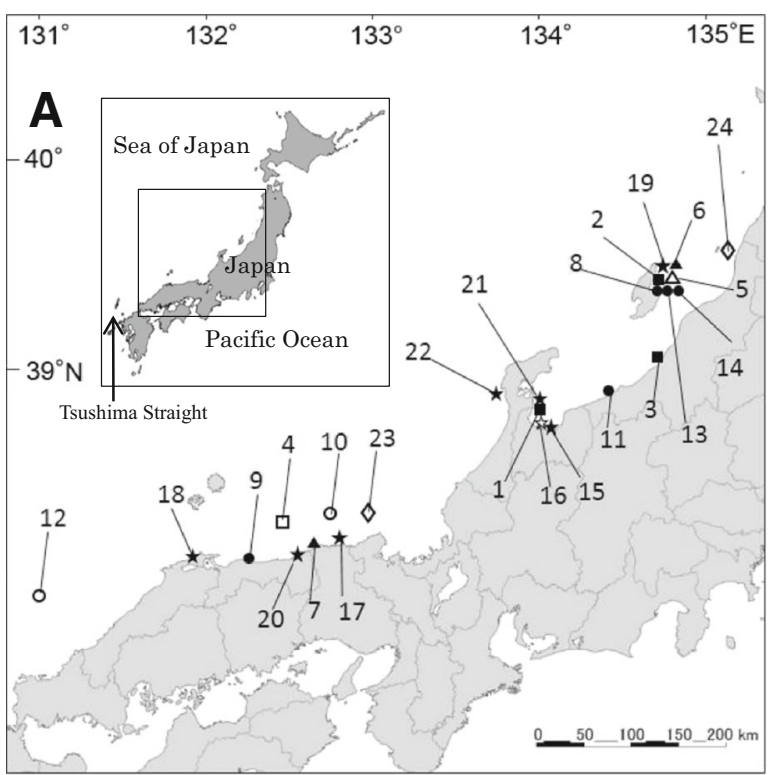

Fig. 1 Positions at which giant squid were found during JanuaryMay 2014 (a) and September 2014-March 2015 (b). The numbers correspond to the ID numbers in Table 1. a $\mathbf{m}$ : January 2014, $\mathbf{\Delta}$ :

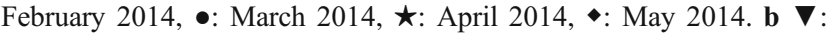
September 2014, +: October 2014, $\bullet:$ November 2014, $\star$ : December

\section{Situation at finding}

Among the 57 cases, 28 individuals were found alive, 22 were found dead, and this information was unavailable for seven (Fig. 4). All specimens were grouped according to distance from the shore and depth at which they were found: (1) individual washed ashore onto a beach or found floating at the surface close to a beach (19 cases); (2) individual was caught by a fixed net set in coastal waters at depths between 50 and $150 \mathrm{~m}$ (28 cases); (3) individual was caught by bottom trawl or bottom gillnet fisheries operating several kilometers off shore at depths between 200 and $300 \mathrm{~m}$ (ten cases) (Fig. 5). Half of these were trapped in fixed nets set in coastal waters shallower than $150 \mathrm{~m}$ depth (Table 1)).

\section{Biological information}

The DML of 36 of the 57 individuals was measured, the BL was measured for 31 , and the TL, including tentacles, was measured for 20. BW was roughly measured in 20 individuals and sex was determined in 19 individuals (Table 2). DML, $\mathrm{BL}$, TL, and BW ranged between 84-196 cm, 270-446 cm, $260-637 \mathrm{~cm}$, and $25.2-\mathrm{ca} .200 \mathrm{~kg}$, respectively. The sex ratio was eight females to five males. The measurements recorded for each specimen varied, so the summary that follows also varies in what can be summarized. The smallest female was $84 \mathrm{~cm}$ DML, $448 \mathrm{~cm} \mathrm{TL}$, and $33.2 \mathrm{~kg} \mathrm{BW}$, and the smallest male was $91 \mathrm{~cm}$ DML, $394 \mathrm{~cm} \mathrm{TL}$, and $25.2 \mathrm{~kg} \mathrm{BW}$. The largest female was $196 \mathrm{~cm} \mathrm{DML,} 446 \mathrm{~cm} \mathrm{BL}$, and ca. $200 \mathrm{~kg}$ $\mathrm{BW}$, and the largest male was $150 \mathrm{~cm} \mathrm{DML,} 350 \mathrm{~cm} \mathrm{BL}$, and

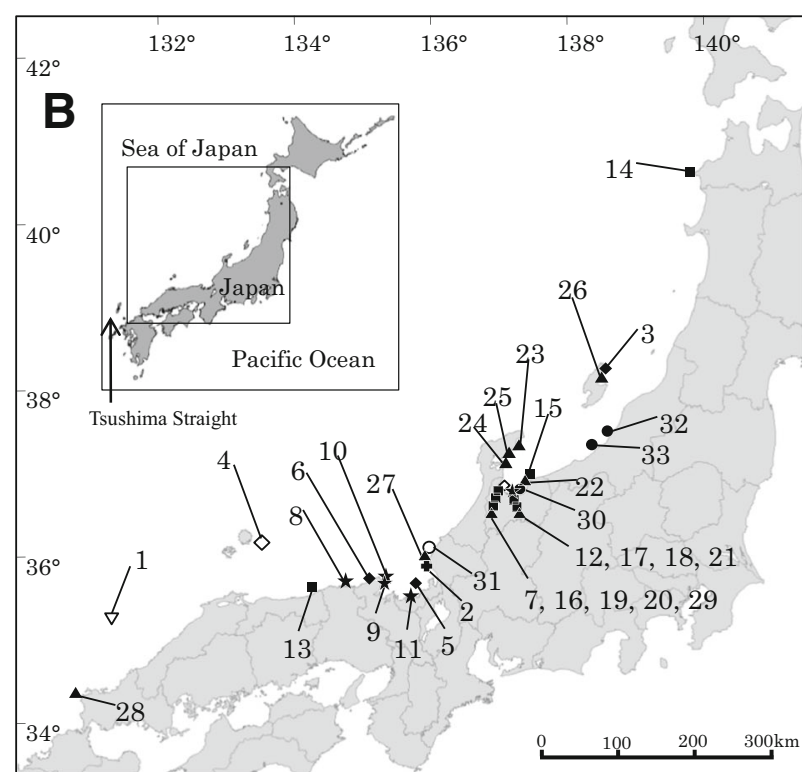

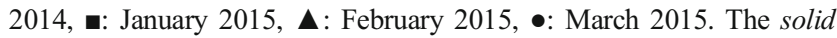
symbols indicate individuals stranded on beaches, drifting at the surface, and/or found in fixed nets, while the open symbols indicate individuals caught by bottom trawl nets or bottom gillnets

BW unknown. Two size groups were recognized, one with a DML of 80-160 $\mathrm{cm}$ with a mode at $110 \mathrm{~cm}$ and another with a DML of $>160 \mathrm{~cm}$ with a mode at $170 \mathrm{~cm}$ (Fig. 6). The former group had a nearly equal sex ratio. The latter group was all females except for unexamined individuals.

\section{Discussion}

The Sea of Japan is a $978,000-\mathrm{km}^{2}$ marginal sea, located in the western periphery of the North Pacific. It is bordered by the Eurasian continent to the west and the Japanese archipelago to the east, and is connected to the Okhotsk Sea through the narrow Soya Strait to the north, to the North Pacific through Tsugaru Strait in the east, and to the East China Sea through the narrow Tsushima Strait to the south. The average depth is about $1667 \mathrm{~m}$ and its deepest point is $3742 \mathrm{~m}$. The warm Tsushima Current flows into the Sea of Japan through Tsushima Strait from the south and runs along the Japanese coast to the north and flows out through Tsugaru Strait into the North Pacific and through Soya Strait into the Okhotsk Sea. Due to the narrow (ca. 200-km width) and shallow (90-130-m depth) geography of Tsushima Strait, limited water circulation occurs in the upper layers shallower than ca. $300 \mathrm{~m}$ depth. Deeper than that, so-called "Japan Sea Proper Water", which is characterized by extremely cold $\left(0-1{ }^{\circ} \mathrm{C}\right)$ and high salinity (34.1 PSU) water, is distributed throughout the Sea of Japan (http://www.jma-net.go.jp/jsmarine/japansea.html).

Giant squid are estimated to live in mesopelagic waters of temperate open oceans (Clarke 1966; Roper and Boss 1982). 
Table 2 Biological date of the giant squids summarized in Table 1

\begin{tabular}{|c|c|c|c|c|c|c|c|c|}
\hline ID no. & DML (cm) & $\mathrm{BL}(\mathrm{cm})$ & $\mathrm{TL}(\mathrm{cm})$ & BW (kg) & Sex & Condition & Tentacle & Remarks \\
\hline A-1 & - & 350 & - & - & - & Dead & Absent & \\
\hline A-2 & 187 & 406 & - & 163 & $\mathrm{~F}$ & Alive & Absent & \\
\hline A-3 & - & - & - & - & - & Dead & Absent & $\begin{array}{l}\text { Only head and arms. } \\
\text { Arm length } 1.2 \mathrm{~m}\end{array}$ \\
\hline A-4 & 170 & 340 & - & - & $\mathrm{F}$ & Alive & Absent & \\
\hline A-5 & 136 & 305 & - & ca. 100 & $\mathrm{M}$ & Alive & Absent & \\
\hline A-6 & 91 & - & 394 & 25.2 & M & Alive & Present & \\
\hline A-7 & - & 410 & - & ca. 200 & $\mathrm{~F}$ & Alive & Absent & \\
\hline A-8 & 135 & 285 & - & - & $\mathrm{F}$ & Dead & Absent & \\
\hline A-9 & 120.8 & - & 462.5 & - & - & Dead & - & \\
\hline A-10 & 123 & - & 430 & 50 & - & Dead & Present & \\
\hline A-11 & 196 & 446 & - & ca. 200 & $\mathrm{~F}$ & Dead & Absent & \\
\hline A-12 & 116 & 270 & 570 & - & M & - & Present & \\
\hline A-13 & 84 & - & 448 & 33.2 & $\mathrm{~F}$ & Alive & Present & \\
\hline A-14 & 110 & - & 435 & 37.7 & $\mathrm{M}$ & Alive & Present & \\
\hline A-15 & 150 & 350 & - & - & M & Alive & Absent & \\
\hline A-16 & 110 & 275 & 510 & - & - & Alive & Present & \\
\hline A-17 & 112 & - & 594 & - & - & Dead & Present & \\
\hline A-18 & - & - & ca. 500 & - & - & Alive & - & \\
\hline A-19 & ca. 100 & - & - & - & - & - & - & \\
\hline A-20 & 121.5 & - & 637 & - & $\mathrm{F}$ & Dead & Present & \\
\hline A-21 & - & - & 480 & 30 & - & Dead & Present & \\
\hline A-22 & 111 & 289 & 565 & 60 & $\mathrm{~F}$ & Alive & Present & \\
\hline A-23 & ca. 100 & - & - & - & - & Dead & - & \\
\hline A-24 & 92 & - & 420 & - & - & - & Present & \\
\hline B1 & 140 & 314 & - & - & M & - & Absent & \\
\hline B-2 & 117 & 264 & 288 & ca. 40 & $\mathrm{M}$ & Dead & Absent & \\
\hline B-3 & - & - & 260 & - & - & - & Present & \\
\hline B-4 & 183.5 & - & - & 130 & $\mathrm{~F}$ & Dead & Absent & Head and mantle separated \\
\hline B-5 & 137 & - & 740 & ca. 60 & - & Alive & Present & Good condition \\
\hline B-6 & - & - & - & - & - & Dead & Absent & $\begin{array}{l}\text { Only head and arms. } \\
\text { Arm length } 1.2 \mathrm{~m}\end{array}$ \\
\hline B-7 & 155 & - & 630 & - & - & Alive & Present & \\
\hline B-8 & - & 350 & - & ca. 100 & - & Dead & Absent & \\
\hline B-9 & - & 320 & - & ca. 70 & - & Alive & Absent & \\
\hline B-10 & 178 & - & 507 & ca. 100 & - & Dead & One side only & \\
\hline B-11 & - & ca. 300 & - & - & - & Alive & Absent & \\
\hline B-12 & - & - & - & - & - & Alive & Absent & \\
\hline B-13 & 180.5 & 355 & - & - & - & Dead & Absent & \\
\hline B-14 & 127 & - & - & - & M & Dead & Absent & \\
\hline B-15 & - & 420 & - & - & - & - & Absent & \\
\hline B-16 & ca. 200 & - & ca. 600 & ca. 200 & - & Alive & - & \\
\hline B-17 & - & ca. 300 & - & - & - & Alive & - & \\
\hline B-18 & ca. 200 & - & ca. 600 & - & - & Alive & Present & \\
\hline B-19 & 170 & ca. 400 & - & - & - & Alive & Absent & \\
\hline B-20 & - & - & - & - & - & Alive & - & \\
\hline B-21 & ca. 200 & ca. 400 & - & - & - & Alive & Absent & \\
\hline B-22 & - & ca. 400 & - & - & - & - & - & \\
\hline B-23 & - & 335 & - & - & - & Alive & - & \\
\hline B-24 & - & 420 & - & ca. 200 & - & Alive & Absent & \\
\hline B-25 & - & 360 & - & ca. 150 & - & Alive & Absent & \\
\hline B-26 & - & 415 & - & - & - & Alive & Absent & \\
\hline B-27 & 175 & 377 & - & - & $\mathrm{F}$ & Dead & Absent & \\
\hline B-28 & - & 286 & - & 65.5 & - & Dead & Absent & \\
\hline B-29 & - & $250-300$ & - & - & - & Alive & - & \\
\hline B-30 & ca. 200 & - & - & - & - & Alive & - & \\
\hline B-31 & 177 & 376 & - & - & $\mathrm{F}$ & Dead & Absent & Empty stomach \\
\hline B-32 & 161 & 327 & - & - & - & Dead & Absent & \\
\hline B-33 & 190 & 360 & - & - & - & Dead & Absent & \\
\hline
\end{tabular}

Kubodera and Mori (2005) revealed that a giant squid off the Ogasawara Islands in the North Pacific appeared at $900 \mathrm{~m}$ depth and swam up to $600 \mathrm{~m}$ to escape from a jig on which its tentacle was hooked. They reported that the water temperatures at 900 and $600 \mathrm{~m}$ depth were about 4 and $6{ }^{\circ} \mathrm{C}$, respectively. This evidence suggests that giant squid in the Sea of Japan might not be permanent residents but, rather, migrants from the south, passing through bottom layer waters of the Tsushima Strait when the water temperature there decreases to below ca. $6{ }^{\circ} \mathrm{C}$ in mid-winter to early spring. Once they have traveled into the Sea of Japan, water temperatures in the deep layer are too cold and they probably move through the water column to the more suitable temperature zone between the warm surface layer and the cold Japan Sea Proper Water during summer to fall.

Okiyama (1993) suggested a possible reason for why giant squid have been occasionally found dead on beaches or caught in fixed nets set in Japanese coastal waters of the Sea of Japan during winter to early spring. At the beginning of winter, the surface water is cooling down 


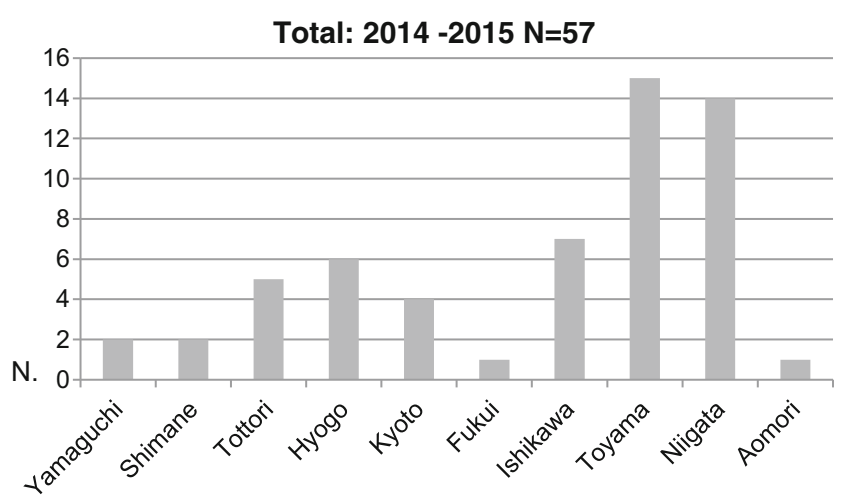

Fig. 2 Regional occurrences of giant squid along the Japanese coast of the Sea of Japan from Yamaguchi Prefecture to Aomori Prefecture (i.e., south to north)

from the northern peripheries along the continental coasts and the cold surface water at $0-1{ }^{\circ} \mathrm{C}$ subsides into deeper stratum, which is the origin of the Japan Sea Proper Water. Cold water subsidence commences from the north and gradually extends to the south as winter progresses. This cold water movement might reduce the suitable temperature habitat of the giant squid both horizontally and vertically. They are forced to move southward and to shallower depths. Some individuals would be weakened by exposure to extremely cold waters and then transported by eddies of the Tsushima Current and strong northwesterly seasonal winds, which would result in them coming closer to Japanese coastal waters and explain them being trapped in fixed nets and/or becoming stranded on beaches along the Japanese coast.

Although this is one possible explanation for the occurrence of giant squid in Japanese coastal waters of the Sea of Japan, the unusual mass findings of giant squid in 2014 and 2015 are likely due to a different mechanism. Judging from 10-day and monthly mean water temperature anomalies at the surface and $100 \mathrm{~m}$ depths during the winter seasons of 2014 and 2015, the water temperatures at these depths were apparently lower in both years than usual, especially in January 2014 and February 2015. Prominent large-scale cold water masses that developed in the middle layer of the central portion of the Sea of Japan in 2014 and 2015 might have worked strongly to carry the giant squid to the surface layer and towards the Japanese coast. In addition, although there were few records of giant squid during 2008-2013 (Kubodera, personal observation), it is possible that a number of giant squid entered the Sea of Japan during these years and survived there until 2014.

One of the important biological findings of giant squid deduced from the recent mass findings is the bimodal size frequency distribution (80-160 $\mathrm{cm}$ DML with a mode at $110 \mathrm{~cm}$ and $160-190 \mathrm{~cm}$ DML with a mode at $170 \mathrm{~cm}$ DML) in winter season. The smaller group had a nearly even sex ratio and the larger group was comprised entirely of females. Wada et al. (2015) recently reported that two young giant squid measuring $33 \mathrm{~cm}$ DML were caught by purse seine net in the southwestern Sea of Japan on June 14, 2013. Assuming that a young giant squid measuring $33 \mathrm{~cm}$ DML in June grows to $110 \mathrm{~cm}$ DML by January, the monthly growth rate would be ca. $11 \mathrm{~cm}$ DML. This value represents very rapid growth and an inclination towards an S-growth curve, with lower growth rates in earlier and later life stages. The overall size composition of giant squid in the Sea of Japan suggests a longevity of 2 years for males and 3 years for females.

Roper and Shea (2013) reviewed current knowledge on the taxonomy and systematics, distribution, population size, habitat use, age and growth, predation and feeding, reproduction and life cycles, and functional morphology of giant squid and found wide gaps. The present mass findings of 57 individuals within a relatively short period of time, two winter seasons between 2014 and 2015, and
Fig. 3 Monthly occurrences of giant squid along the Japanese coast of the Sea of Japan from January to March 2015 by sex (blue: male, pink: female, gray: undetermined)

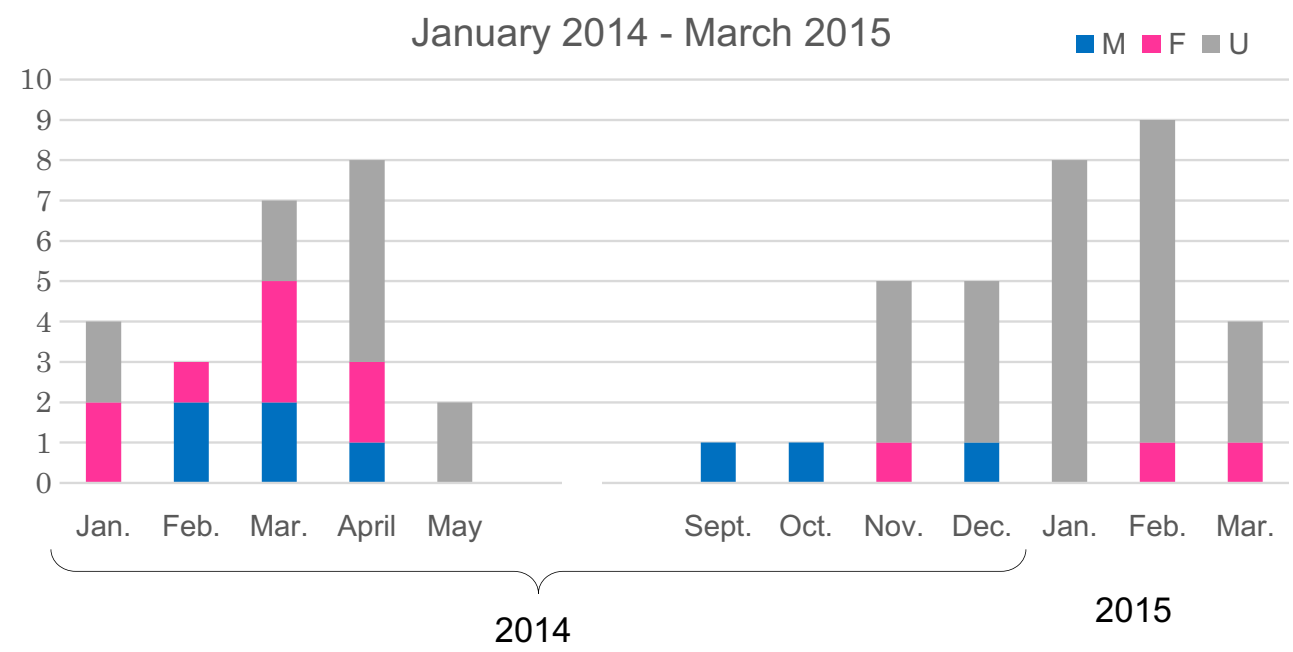

2014 


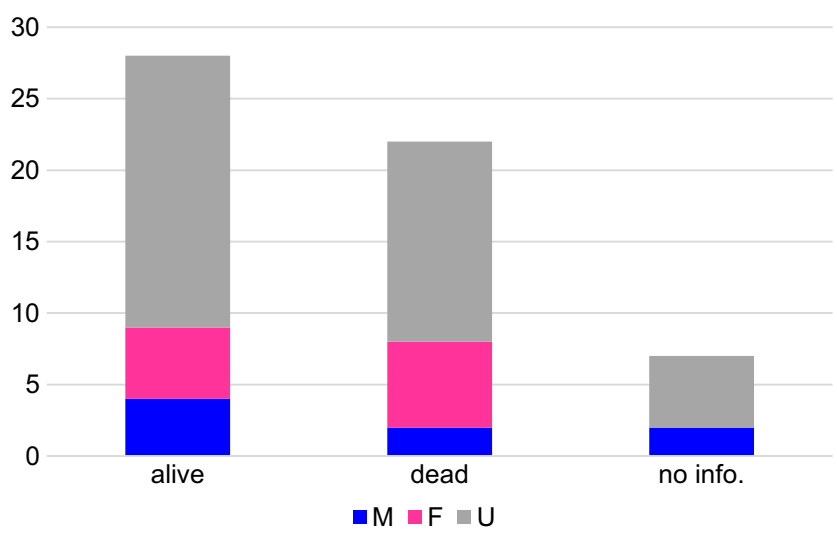

Fig. 4 Frequencies of individuals found dead and alive by sex: blue: male $(M)$, pink: female $(F)$, gray: undetermined (U)

a restricted area of Japanese coast of the Sea of Japan have greatly increased the available information necessary to understand the natural history of giant squid.

Roper et al. (2015) investigated records of giant squid that were discovered in the western North Atlantic Ocean between Newfoundland and the Gulf of Mexico and provided detailed information on 28 individuals found during 1952-2011. They recognized a general upwards trend in the number of sightings in the 1990s and 2000s, reflecting the increased scientific awareness and growing popular interest in giant squid. In Japan, we had two large events concerning giant squid in 2013. One was a TV program airing on Japan's national public broadcasting organization, NHK, in January, which broadcast the first encounter with a live giant squid using a manned submersible in the deep sea off the Ogasawara Islands. The other was a special exhibition entitled "The Deep" held at the National Museum of Nature and Science in Tokyo from July to September, in which a preserved giant squid specimen as well as videos of live giant squid filmed for the first time were introduced. These two events made Japanese people, especially the younger generations, become more interested in the giant squid. Such a boom in attention directed towards giant squid and other deep-sea creatures likely increases the awareness of

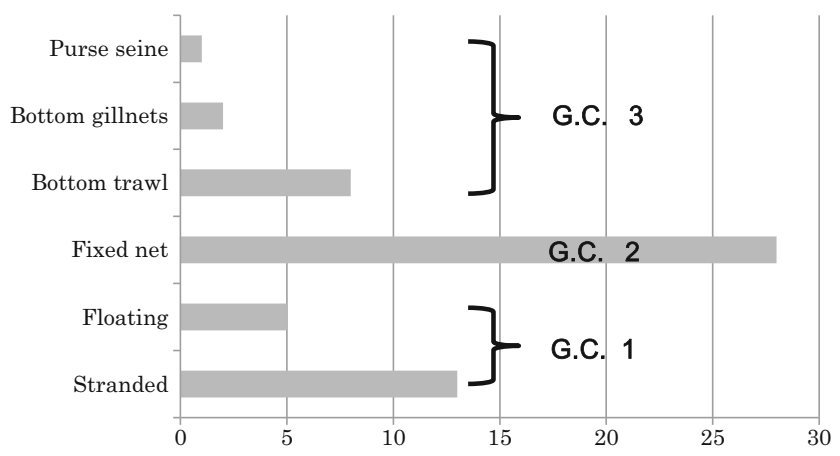

Fig. 5 Frequency of individuals found stranded on a beach, floating at the surface, caught in a fixed net, caught by a bottom trawl net, caught in a bottom gillnet, and caught by purse seine, categorized into three groups based on distance from the shore and depth at which they were found

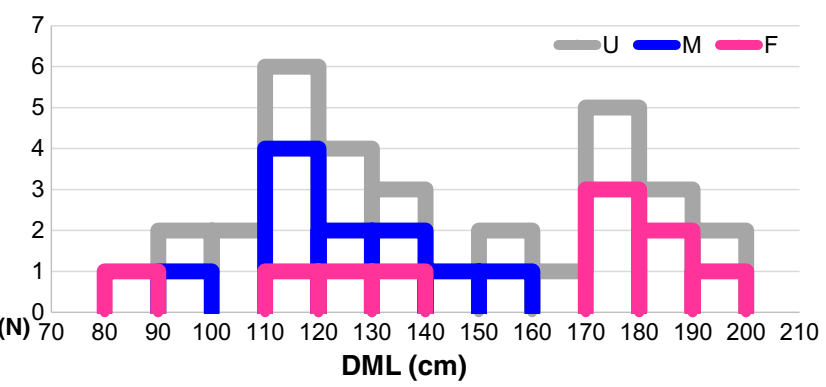

Fig. 6 Size (dorsal mantle length in $\mathrm{cm}$ ) frequency distribution of giant squids $(N=32)$ found in the coastal waters of the Sea of Japan during January 2014 to March 2015

giant squid among people in coastal regions and encourages them to alert the media and local experts to any findings.

We also suggest that the Sea of Japan may work as a large natural trap for giant squid migrating from the south during early spring. Their distribution spreads widely into the midlayers, which are within their suitable water temperature zone, and they continue to grow during summer and fall. In winter, the oceanographic characteristics of the Sea of Japan may compel giant squid to move southward and to shallower surface waters, where the coastal eddy of the Tsushima Current and strong westward seasonal winds may carry them to Japanese coastal waters, where they become entangled in fixed nets or stranded on beaches. For future "giant squid" research, the Japanese coasts of the Sea of Japan during the winter months would be the most suitable area to encounter live giant squid.

Acknowledgements We would like to offer our special thanks to the following people who provided us with valuable information: $\mathrm{K}$. Minowa (Kashiwazaki City Museum), T. Yamaguchi (NHK Japan Broadcasting Corporation), M. Baba (Joetsu Aquarium Museum), T. Fujita (Shimane Aquarium), S. Ikeguchi (Notojima Seaside Park), Y. Ueno (Fisheries Technology Department, Kyoto Prefectural Agriculture, Forestry and Fisheries Technology Center), S. Sasai (Echizen Matsushima Aquarium), K. Ichisawa (Tottori Prefectural Museum), E. Kongozaki (Ajigasawa Fisheries Office), and M. Kanbayashi (Kitanihon Broadcasting).

Open Access This article is distributed under the terms of the Creative Commons Attribution 4.0 International License (http:// creativecommons.org/licenses/by/4.0/), which permits unrestricted use, distribution, and reproduction in any medium, provided you give appropriate credit to the original author(s) and the source, provide a link to the Creative Commons license, and indicate if changes were made.

\section{References}

Clarke MR (1966) A review of the systematics and ecology of oceanic squids. Adv Mar Biol 4:91-300

Clarke MR (1980) Cephalopoda in the diet of sperm whales of the southern hemisphere and their bearing on sperm whale biology. Discov Rep 37:1-324 
Ellis R (1998) The search for the giant squid. Lyons Press, Guilford, CT Förch EC (1998) The marine fauna of New Zealand: Cephalopoda: Oegopsida:Architeuthidae (giant squid). National Institute of Water Atmospheric Research (NIWA) Biodiversity Memoir 110, 113 pp

Hilgendorf F (1880) Über einen riesigen Tintenfisch aus Japan. Megateuthis martensii g.n., sp.n. Sitzungsbericht Gesellschaft naturforschender Freude, Berlin, 4, pp 65-67 (in German)

Honma Y, Kitami T, Mizusawa R (1983) Records of cephalopoda in the waters adjacent to Niigata and Sado Island in the Japan Sea, based partially on the pelagic squids stranded ashore. Bull Biogeogr Soc Jpn 38(12):23-29 (in Japanese with English abstract)

Kubodera T (2013) Miracle encounter of the giant squid. Shinchosha, Tokyo, $180 \mathrm{pp}$ (in Japanese)

Kubodera T, Mori K (2005) First-ever observations of a live giant squid in the wild. Proc R Soc Lond B Biol Sci 272:2583-2586. doi:10.1098/rspb.2005.3158, 4 pp

Mitsukuri K, Ikeda S (1895) Notes on a gigantic cephalopod. Zool Mag Tokyo 7:39-50

Nishimura S (1968) A preliminary list of the pelagic cephalopoda from the Japan Sea. Publication of the Seto Marine Biological Laboratory XVI(1):71-83

Okiyama M (1993) Kinds, abundance and distribution of the oceanic squids in the Sea of Japan. In: Okutani T, O’Dor RK, Kubodera T (eds) Recent advances in cephalopod fisheries biology. Tokai University Press, Tokyo, pp 404-451

Pfeffer G (1912) Die cephalopodan der plankton expedition. Zugleicheine monographisc heuebersicht der oegopsiden cephalopodan. Ergebnisse der Plankton Expedition der Humboldt Stiftung 2:1-815 (in German)

Roeleveld MAC, Lipinski MR (1991) The giant squid Architeuthis in southern African waters. J Zool 224:431-477
Roper CFE, Boss KJ (1982) The giant squid. Sci Am 246:82-89

Roper CFE, Shea EK (2013) Unanswered questions about the giant squid Architeuthis (Architeuthidae) illustrate our incomplete knowledge of coleoid cephalopods. Am Malacol Bull 31(1):109-122

Roper CFE, Judkins H, Voss NA, Shea E, Dawe E, Ingrao D, Rothman PL, Roper IH (2015) A compilation of recent records of the giant squid, Architeuthis dux (Steenstrup, 1857) (Cephalopoda) from the western North Atlantic Ocean, Newfoundland to the Gulf of Mexico. Am Malacol Bull 33(1):78-88

Sasaki M (1916) Notes on oegopsid cephalopods found in Japan. Annotationes Zoologicae Japonenses 9:89-120

Sasaki M (1929) A monograph of the dibranchiate cephalopods of the Japanese and adjacent waters. J Fac Agric Hokkaido Imp Univ 20(suppl): $1-357$

Steenstrup J (1857) Oplysninger om Atlanterhavets colossale Blaeksprutter. Forhandlinger ved de Skandinaviske Naturforskeres Syvende Mode 7:182-185 (in Danish)

Taki I (1965) Class cephalopoda. In: Uchida T (eds) New illustrated encyclopedia of the fauna of Japan, pt. II. Hokuryu-kan Publishing, Tokyo, pp 307-326 (in Japanese)

Wada T, Kubodera T, Yamada M, Terakado H (2015) First records of small-sized young giant squid Architeuthis dux from the coasts of Kyushu Island and the south-western Sea of Japan. Mar Biodivers Rec 8:1-8

Winkelmann I, Campos PF, Strugnell J, Cherel Y, Smith PJ, Kubodera T, Allcock L, Kampmann ML, Schroeder H, Guerra A, Norman M, Finn J, Ingrao D, Clarke M, Gilbert MTP (2013) Mitochondrial genome diversity and population structure of the giant squid Architeuthis: genetics sheds new light on one of the most enigmatic marine species. Proc R Soc Lond B Biol Sci 280:20130273 